\title{
PLOD2 wt Allele
}

National Cancer Institute

\section{Source}

National Cancer Institute. PLOD2 wt Allele. NCI Thesaurus. Code C162520.

Human PLOD2 wild-type allele is located in the vicinity of 3q24 and is approximately $94 \mathrm{~kb}$ in length. This allele, which encodes procollagen-lysine,2-oxog lutarate 5-dioxygenase 2 protein, plays a role in post-translational protein modification and collagen fibril stabilization. Mutation of the gene is associated with Bruck syndrome type 2. 